\title{
TREATMENT OF AGGRESSIVE GIANT CELL TUMOR: INTRALESIONAL CURETTAGE VS RESECTION ENDOPROTHESIS A SYSTEMATIC REVIEW/META ANALYSIS
}

\author{
Mohamed Abd Elrahman Mostafa, Sherif Ishak Azmy \& \\ Hany Farouk Abd El Adel El Sawy *
}

\author{
Orthopaedic Surgery \\ Department, Faculty of \\ Medicine, Ain Shams \\ University \\ *Corresponding Author: \\ Hany Farouk Abd El Adel El- \\ Sawy \\ Phone No.: (+2) 01016033578 \\ E-mail: hany- \\ elsawy@hotmail.com \\ Received: $1 / 9 / 2020$ \\ Accepted: 22/9/2020
}

Online ISSN: 2735-3540

\begin{abstract}
Background: Giant cell tumors (GCT) are benign tumors that may have aggressive behavior, it is usually found peri-articular, (Distal femur, proximal tibia, distal radius) with unclear pathogenesis.
\end{abstract}

Aim of the Work: To detect best method of treatment of aggressive giant cell tumor whether intralesional curettage or resection and replacement with endoprothesis.

Patients and Methods: This review was a randomized controlled trial that studied the lines of surgical treatment of aggressive giant cell tumor. This review included studies that were published in English, studies that included surgical treatment only not conservative treatment and studies that published on PubMed or Medline.

Results: As regard the tumor location, the number of sample cases was 315, including 169 cases distal Femur and 146 Case proximal tibia with no statistical significant difference between the included studies. Regarding the follow up time, the number of sample cases was 166 with highly statistical significant difference between the included studies.

Conclusion: Throughout this systematic review, we concluded that Wide resection and extended curettage using adjuvants in treatment of patients with giant cell tumor were equally effective with no statistically significant differences in complications.

Keywords: Giant Cell Tumor - Intralesional Curettage Resection Endoprothesis

\section{INTRODUCTION:}

Giant cell tumors (GCT) are benign tumors that may have aggressive behavior, it is usually found peri-articular, (Distal femur, proximal tibia, distal radius) with unclear pathogenesis $^{(1,2,3)}$.

GCT has high recurrence rate as regard of being benign tumor with small percentage of metastasis ${ }^{(1,2)}$.

GCT is usually presented with pain and limited range of motion due to close proximity to the joints with $12 \%$ of patients presented at first by pathological fracture ${ }^{(4,5)}$, presentation with a pathological fracture is thought to indicate more aggressive disease with a high risk of local recurrence and metastatic spread $^{(5,6,7)}$.

It is usually treated surgically with intralesional curettage being the preferred modality to preserve the anatomy of the bone bearing in mind the young age of affected grou ${ }^{(8,9,10)}$. 
Various studies suggest that wide resection is associated with a decreased risk of local recurrence when compared with intralesional curettage and may increase the recurrence free interval rate from $84 \%$ to $100 \%{ }^{(6,11,12,13)}$.

However, wide resection is associated with higher rates of surgical complications and lead to functional impairment, generally necessitating reconstruction ${ }^{(13,14,15,16)}$.

GCT is considered aggressive when possessing the following features: wide zone of transition, cortical thinning, expansile remodeling, or even cortical bone destruction, with an associated soft-tissue mass.

Additionally, it may also contain freefluid levels due to secondary $\mathrm{ABC}$ formation which may occur in up to $14 \%$ cases of bone GCT. It may be differentiated from the primary $\mathrm{ABC}$ by the presence of an enhancing soft tissue component.

\section{AIM OF THE WORK:}

To detect best method of treatment of aggressive giant cell tumor whether intralesional curettage or resection and replacement with endoprothesis.

\section{PATIENTS AND METHODS:}

Criteria for considering studies for this review:

\section{Types of studies:}

This review was a randomized controlled trial that studied the lines of surgical treatment of aggressive giant cell tumor. This review included studies that were published in English, studies that included surgical treatment only not conservative treatment and studies that published on PubMed or Medline.

\section{Types of participants:}

Participants were adults with giant cell tumor that showing aggressive behavior with established diagnosis of giant cell tumor and early stage of the disease or patients with pathological fractures were excluded.

\section{Types of interventions:}

Comparative study between intralesional curettage versus resection endoprothesis as regard their postoperative results and rate of recurrence.

\section{Types of outcome measures:}

The following outcome measures were taken in consideration:

a) Post-operative range of motion.

b) Rate of recurrence.

c) Affection of daily activities.

\section{Methods of the review:}

\section{Locating and selecting studies:}

We searched the following electronic bibliographic databases: Egyptian Universities Researches, Medline, pub med, medical journals.

\section{Statistical considerations:}

Outcomes from included trials were combined using the review manager software.

\section{Analysis of the results was based on:}

a) Age.

b) Range of motion.

c) Affection of daily activities.

d) Recurrence rate.

\section{Statistical analysis:}

Using our search syntax, a total of 1236 articles were found. In total, 140 were identified from PubMed, 1096 from Proquest library and none from the Cochrane Register of Controlled Trials after the initial search. The duplicated articles were removed and 215 articles were identified using the inclusion and exclusion criteria. A total of 172 were excluded on the basis of title and review of the abstract. The full texts of the remaining 43 papers were reviewed and 38 were excluded. We finally selected 18 articles presented in (Figure 1) for the meta-analysis. 


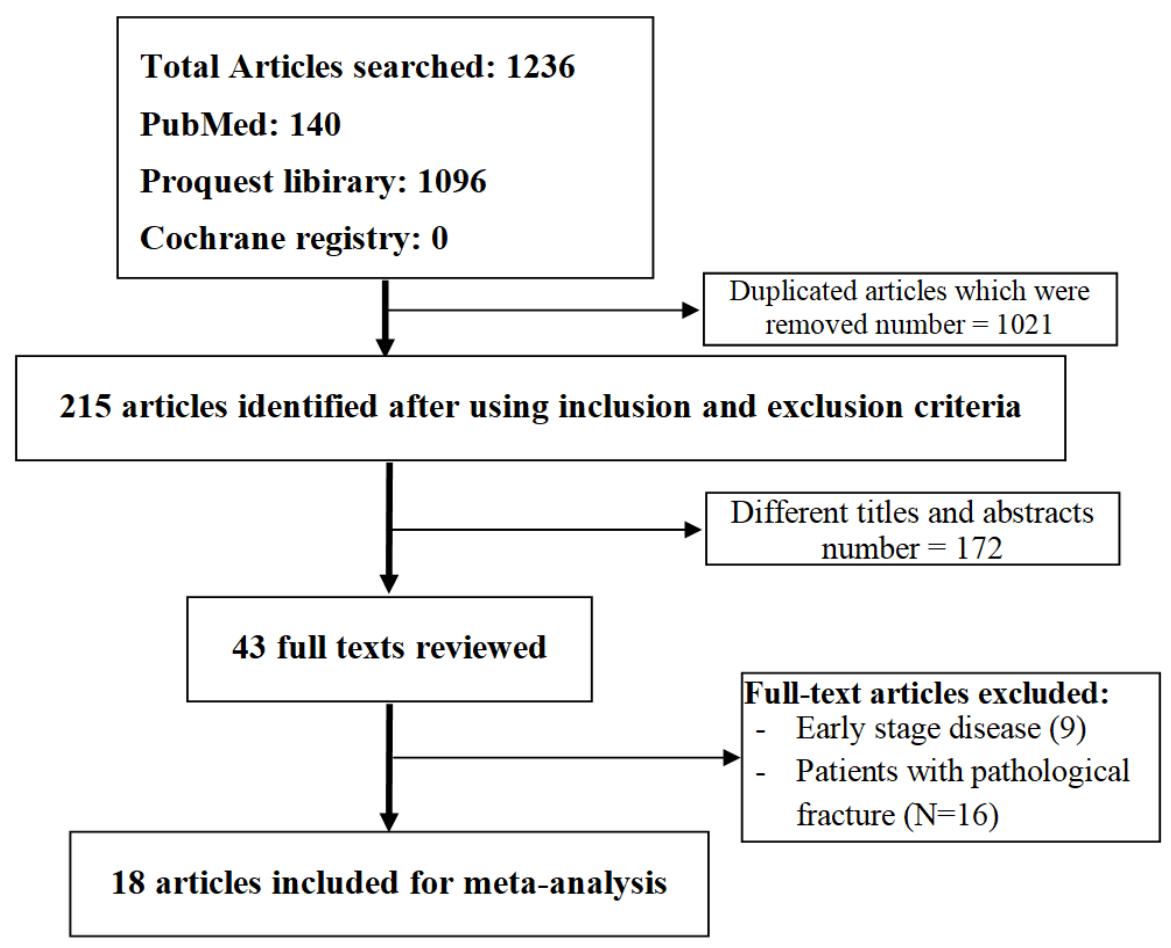

Figure (1): Flow chart of the search for relevant articles.

Data were collected, revised, coded and entered to the Statistical Package for Social Science (IBM SPSS) version 20. The qualitative data were presented as number and percentages while quantitative data were presented as mean, standard deviations and ranges when their distribution found parametric.

The comparison between two groups with qualitative data were done by using Chi-square test and/or Fisher exact test was used instead of Chi-square test when the expected count in any cell was found less than 5.
The comparison between two independent groups with quantitative data and parametric distribution was done by using Independent t-test.

The confidence interval was set to $95 \%$ and the margin of error accepted was set to $5 \%$. So, the p-value was considered significant as the following:

- $\quad \mathrm{P}>0.05=$ non significant (NS)

- $\quad \mathrm{P}<0.05=$ significant $(\mathrm{S})$

- $\quad \mathrm{P}<0.001=$ highly significant $(\mathrm{HS})$. 


\section{RESULTS:}

Table (1): Descriptive Data of the included studies $(\mathrm{N}=18)$

\begin{tabular}{|c|c|}
\hline Papers & No. of Patient \\
\hline Yu et al. ${ }^{(17)}$ & 19 \\
\hline Wan et al. ${ }^{(18)}$ & 27 \\
\hline Zhang et al. ${ }^{(19)}$ & 126 \\
\hline Rigollino et al. ${ }^{(20)}$ & 9 \\
\hline Bai et al. ${ }^{(21)}$ & 27 \\
\hline He et al. ${ }^{(22)}$ & 93 \\
\hline Kamal and Muhamad $^{(23)}$ & 41 \\
\hline Dahlin et al. ${ }^{(24)}$ & 37 \\
\hline Goldenberg et al. ${ }^{(25)}$ & 136 \\
\hline Larsson et al. ${ }^{(4)}$ & 30 \\
\hline Sheth et al. (26) & 52 \\
\hline Sung et al. ${ }^{(14)}$ & 34 \\
\hline McDonald et al. ${ }^{(13)}$ & 85 \\
\hline Jacobs and Clemency ${ }^{(27)}$ & 12 \\
\hline Campanacci et al. ${ }^{(12)}$ & 151 \\
\hline Waldram and Sneath ${ }^{(28)}$ & 19 \\
\hline O’Donnell et al. ${ }^{(29)}$ & 60 \\
\hline Blackley et al. ${ }^{(30)}$ & 59 \\
\hline
\end{tabular}

The previous table shows the number of patients sample for each of the previous 18 papers.

Table (2): Descriptive Data of the included studies in Recurrence $(\mathrm{N}=295)$ and Non Recurrence $(\mathrm{N}=686)$

\begin{tabular}{|c|c|c|c|c|}
\hline \multirow{2}{*}{ Papers } & \multicolumn{2}{|c|}{ Recurrence } & \multicolumn{2}{|c|}{ Non recurrence } \\
\hline & No. & $\%$ & No. & $\%$ \\
\hline Yu et al. ${ }^{(17)}$ & 0 & $0.0 \%$ & 19 & $2.8 \%$ \\
\hline Wan et al. ${ }^{(18)}$ & 3 & $1.0 \%$ & 24 & $3.5 \%$ \\
\hline Zhang et al. ${ }^{(19)}$ & 32 & $10.8 \%$ & 58 & $8.5 \%$ \\
\hline Rigollino et al. ${ }^{(20)}$ & 4 & $1.4 \%$ & 5 & $0.7 \%$ \\
\hline Bai et al. ${ }^{(21)}$ & 3 & $1.0 \%$ & 24 & $3.5 \%$ \\
\hline He et al. (22) & 21 & $7.1 \%$ & 72 & $10.5 \%$ \\
\hline Kamal and Muhamad ${ }^{(23)}$ & 3 & $1.0 \%$ & 38 & $5.5 \%$ \\
\hline Dahlin et al. (24) & 15 & $5.1 \%$ & 22 & $3.2 \%$ \\
\hline Goldenberg et al. (25) & 73 & $24.7 \%$ & 63 & $9.2 \%$ \\
\hline Larsson et al. ${ }^{(4)}$ & 14 & $4.7 \%$ & 16 & $2.3 \%$ \\
\hline Sheth et al. ${ }^{(26)}$ & 12 & $4.1 \%$ & 40 & $5.8 \%$ \\
\hline Sung et al. ${ }^{(14)}$ & 14 & $4.7 \%$ & 20 & $2.9 \%$ \\
\hline McDonald et al. ${ }^{(13)}$ & 29 & $9.8 \%$ & 56 & $8.2 \%$ \\
\hline Jacobs and Clemency (27) & 2 & $0.7 \%$ & 10 & $1.5 \%$ \\
\hline Campanacci et al. ${ }^{(12)}$ & 41 & $13.9 \%$ & 110 & $16.0 \%$ \\
\hline Waldram and Sneath ${ }^{(28)}$ & 7 & $2.4 \%$ & 12 & $1.7 \%$ \\
\hline O’Donnell et al. ${ }^{(29)}$ & 15 & $5.1 \%$ & 45 & $6.6 \%$ \\
\hline Blackley et al. ${ }^{(30)}$ & 7 & $2.4 \%$ & 52 & $7.6 \%$ \\
\hline Total & 295 & $100.0 \%$ & 686 & $100.0 \%$ \\
\hline
\end{tabular}

The previous table shows that the number of sample cases is 981, including 295 cases Recurrence and 686 Case Non Recurrence. 
Treatment Of Aggressive Giant Cell Tumor: Intralesional Curettage Vs Resection Endoprothesis..

Table (3): Descriptive Data of the included studies in Recurrence ( $\mathrm{N}=295)$ in Currtage group $(\mathrm{N}=42)$ and Wide resection $(\mathrm{N}=21)$

\begin{tabular}{|c|c|c|c|c|}
\hline \multirow[t]{2}{*}{ Papers } & \multicolumn{2}{|c|}{ Currtage } & \multicolumn{2}{|c|}{ Wide resection } \\
\hline & No. & $\%$ & No. & $\%$ \\
\hline Yu et al. ${ }^{(17)}$ & 0 & $0.0 \%$ & 0 & $0.0 \%$ \\
\hline Wan et al. ${ }^{(31)}$ & 3 & $7.1 \%$ & 0 & $0.0 \%$ \\
\hline Zhang et al. ${ }^{(32)}$ & 22 & $52.4 \%$ & 10 & $47.6 \%$ \\
\hline Rigollino et al. ${ }^{(33)}$ & 4 & $9.5 \%$ & 0 & $0.0 \%$ \\
\hline Bai et al. ${ }^{(34)}$ & 1 & $2.4 \%$ & 2 & $9.5 \%$ \\
\hline He et al. ${ }^{(35)}$ & 12 & $28.6 \%$ & 9 & $42.9 \%$ \\
\hline Total & 42 & $100.0 \%$ & 21 & $100.0 \%$ \\
\hline
\end{tabular}

Table (4): Comparison between 7 papers regarding sex

\begin{tabular}{|c|c|c|c|c|c|c|c|}
\hline \multirow{3}{*}{ Papers } & \multicolumn{4}{|c|}{ Sex } & \multirow{3}{*}{ Test value } & \multirow[t]{3}{*}{ P-value } & \multirow[t]{3}{*}{ Sig. } \\
\hline & \multicolumn{2}{|c|}{ Female } & \multicolumn{2}{|c|}{ Male } & & & \\
\hline & No & $\%$ & No & $\%$ & & & \\
\hline Yu et al. ${ }^{(17)}$ & 9 & $5.5 \%$ & 10 & $5.6 \%$ & $9.957 *$ & 0.126 & NS \\
\hline Wan et al. ${ }^{(18)}$ & 13 & $7.9 \%$ & 14 & $7.9 \%$ & & & \\
\hline Zhang et al. ${ }^{(19)}$ & 56 & $34.1 \%$ & 70 & $39.3 \%$ & & & \\
\hline Rigollino et al. ${ }^{(20)}$ & 2 & $1.2 \%$ & 7 & $3.9 \%$ & & & \\
\hline Bai et al. ${ }^{(21)}$ & 12 & $7.3 \%$ & 15 & $8.4 \%$ & & & \\
\hline He et al. ${ }^{(22)}$ & 44 & $26.8 \%$ & 49 & $27.5 \%$ & & & \\
\hline Kamal and Muhamad ${ }^{(23)}$ & 28 & $17.1 \%$ & 13 & $7.3 \%$ & & & \\
\hline Total & 164 & $100.0 \%$ & 178 & $100.0 \%$ & - & - & - \\
\hline
\end{tabular}

P-value >0.05: Non significant (NS); P-value <0.05: Significant (S); P-value < 0.01: highly significant (HS) *: Chi-square test; $\bullet$ : Independent t-test

This table shows the comparison of gender in only 7 of the 18 Papers, because no data is mentioned for any type in the rest of the Papers, and also shows that the number of sample cases is 342 , including
164 cases Female and 178 Case Male, The Previous table show that there was non statistical significant difference between 7 papers regarding sex.

Table (5): Comparison between 7 papers regarding age

\begin{tabular}{|l|c|c|c|c|}
\hline \multicolumn{1}{|c|}{ Papers } & Age & \multirow{2}{*}{ Test value } & P-value & Sig. \\
\cline { 2 - 2 } & Mean \pm SD & & NS \\
\hline Yu et al. ${ }^{(17)}$ & $35.4 \pm 11.5$ & $0.587 \bullet$ & 0.740 & \\
\hline Wan et al. $^{(18)}$ & $38.03 \pm 10.45$ & & \\
\hline Zhang et al. $^{(19)}$ & $36.15 \pm 9.75$ & & \\
\cline { 1 - 2 } Rigollino et al. $^{(20)}$ & $33.78 \pm 4.68$ & & \\
\cline { 1 - 2 } Bai et al. $^{(21)}$ & $33.07 \pm 12.2$ & & \\
\hline He et al. $^{(22)}$ & $35.6 \pm 11.2$ & & \\
\hline Kamal and Muhamad $^{(23)}$ & $35 \pm 12.93$ & & \\
\hline
\end{tabular}

P-value >0.05: Non significant (NS); P-value <0.05: Significant (S); P-value< 0.01: highly significant $(\mathrm{HS}) *$ : Chi-square test; $\bullet:$ Independent t-test

This table shows the comparison of Age in only 7 of the 18 Papers, because no data is mentioned for any type in the rest of the Papers, and also shows that the number of sample cases is 342 , The Previous table show that there was non statistical significant difference between 7 papers regarding age. 
Table (6): Comparison between 3 papers regarding complications (secondary osteoarthritis, joint stiffness, fracture after complete healing of the lesion, Postoperative fracture, infection, and failure of internal fixation)

\begin{tabular}{|c|c|c|c|c|c|c|c|}
\hline \multirow{3}{*}{ Papers } & \multicolumn{4}{|c|}{ Complications } & \multirow{3}{*}{ Test value } & \multirow{3}{*}{ P-value } & \multirow{3}{*}{ Sig. } \\
\hline & \multicolumn{2}{|c|}{ Yes } & \multicolumn{2}{|c|}{ No } & & & \\
\hline & No. & $\%$ & No. & $\%$ & & & \\
\hline Yu et al. ${ }^{(17)}$ & 0 & $0.0 \%$ & 19 & $8.5 \%$ & $1.432 *$ & 0.489 & NS \\
\hline Zhang et al. ${ }^{(18)}$ & 9 & $60.0 \%$ & 117 & $52.5 \%$ & & & \\
\hline He et al. ${ }^{(22)}$ & 6 & $40.0 \%$ & 87 & $39.0 \%$ & & & \\
\hline Total & 15 & $100.0 \%$ & 223 & $100.0 \%$ & - & - & - \\
\hline
\end{tabular}

P-value >0.05: Non significant (NS); P-value <0.05: Significant (S); P-value< 0.01: highly significant (HS) *: Chi-square test; $\bullet$ : Independent t-test

This table shows the comparison of Complications in only 3 of the 18 Papers, because no data is mentioned for any type in the rest of the Papers, and also shows that the number of sample cases is 238 , including 15 cases Complications and 223 Case Non Complications, The Previous table show that there was non statistical significant difference between 3 papers regarding complications.

Table (7): Comparison between 6 papers regarding tumor location

\begin{tabular}{|c|c|c|c|c|c|c|c|}
\hline \multirow{3}{*}{ Papers } & \multicolumn{4}{|c|}{ Tumor location } & \multirow{3}{*}{ Test value } & \multirow{3}{*}{ P-value } & \multirow{3}{*}{ Sig. } \\
\hline & \multicolumn{2}{|c|}{ Distal Femur } & \multicolumn{2}{|c|}{ Proximal tibia } & & & \\
\hline & No. & $\%$ & No. & $\%$ & & & \\
\hline Yu et al. (17) & 12 & $7.1 \%$ & 7 & $4.8 \%$ & \multirow[t]{6}{*}{$6.134 *$} & \multirow[t]{6}{*}{0.293} & \multirow[t]{6}{*}{ NS } \\
\hline Wan et al. ${ }^{(18)}$ & 10 & $5.9 \%$ & 17 & $11.6 \%$ & & & \\
\hline Zhang et al. ${ }^{(19)}$ & 70 & $41.4 \%$ & 56 & $38.4 \%$ & & & \\
\hline Rigollino et al. ${ }^{(20)}$ & 7 & $4.1 \%$ & 2 & $1.4 \%$ & & & \\
\hline He et al. ${ }^{(22)}$ & 48 & $28.4 \%$ & 45 & $30.8 \%$ & & & \\
\hline Kamal and Muhamad ${ }^{(23)}$ & 22 & $13.0 \%$ & 19 & $13.0 \%$ & & & \\
\hline Total & 169 & $100.0 \%$ & 146 & $100.0 \%$ & - & - & - \\
\hline
\end{tabular}

P-value >0.05: Non significant (NS); P-value <0.05: Significant (S); P-value< 0.01: highly significant (HS) *: Chi-square test; $\bullet:$ Independent t-test

This table shows the comparison of Tumor Location in only 6 of the 18 Papers, because no data is mentioned for any type in the rest of the Papers, and also shows that the number of sample cases is 315 , including
169 cases Distal Femur and 146 Case Proximal tibia, The Previous table show that there was non statistical significant difference between 6 papers regarding tumor location.

Table (8): Comparison between 4 papers regarding follow-up time

\begin{tabular}{|l|c|c|c|c|}
\hline Papers & Follow-up time & Test value & P-value & Sig. \\
\cline { 2 - 2 } & Mean \pm SD & & \\
\hline Yu et al. ${ }^{(17)}$ & $128.9 \pm 51.1$ & $24.470 \bullet$ & 0.000 & HS \\
\cline { 1 - 2 } Wan et al. ${ }^{(18)}$ & $46.8 \pm 14.5$ & & \\
\hline Bai et al. ${ }^{(21)}$ & $92.4 \pm 38.9$ & & \\
\hline He et al. ${ }^{(22)}$ & $69.35 \pm 33.2$ & & \\
\hline
\end{tabular}

P-value >0.05: Non significant (NS); P-value $<0.05$ : Significant (S); P-value $<0.01$ : highly significant $(\mathrm{HS})^{*}$ : Chi-square test; $\bullet$ : Independent t-test

This table shows the comparison of Follow-up time in only 4 of the 18 Papers, because no data is mentioned for any type in the rest of the Papers, and also shows that the number of sample cases is 166, The Previous table show that there was highly statistical significant difference between 4 papers regarding follow-up time. 
Treatment Of Aggressive Giant Cell Tumor: Intralesional Curettage Vs Resection Endoprothesis..

Table (9): Comparison between 5 papers regarding grade

\begin{tabular}{|c|c|c|c|c|c|c|c|c|c|}
\hline \multirow[t]{2}{*}{ Papers } & \multicolumn{2}{|c|}{ Grade I } & \multicolumn{2}{|c|}{ Grade II } & \multicolumn{2}{|c|}{ Grade III } & \multirow{2}{*}{$\begin{array}{c}\text { Test } \\
\text { value }\end{array}$} & \multirow[t]{2}{*}{ P-value } & \multirow[t]{2}{*}{ Sig. } \\
\hline & No. & $\%$ & No. & $\%$ & No. & $\%$ & & & \\
\hline Yu et al. ${ }^{(17)}$ & 0 & $0.0 \%$ & 19 & $12.4 \%$ & 0 & $0.0 \%$ & $55.012 *$ & 0.000 & HS \\
\hline Wan et al. ${ }^{(18)}$ & 0 & $0.0 \%$ & 17 & $11.1 \%$ & 10 & $9.4 \%$ & & & \\
\hline Zhang et al. ${ }^{(19)}$ & 26 & $78.8 \%$ & 67 & $43.8 \%$ & 33 & $31.1 \%$ & & & \\
\hline Bai et al. ${ }^{(21)}$ & 0 & $0.0 \%$ & 17 & $11.1 \%$ & 10 & $9.4 \%$ & & & \\
\hline He et al. ${ }^{(22)}$ & 7 & $21.2 \%$ & 33 & $21.6 \%$ & 53 & $50.0 \%$ & & & \\
\hline Total & 33 & $100.0 \%$ & 153 & $100.0 \%$ & 106 & $100.0 \%$ & - & - & - \\
\hline
\end{tabular}

P-value >0.05: Non significant (NS); P-value <0.05: Significant (S); P-value < 0.01: highly significant (HS) *: Chi-square test; $\bullet$ : Independent t-test

This table shows the comparison of Grade time in only 5 of the 18 Papers, because no data is mentioned for any type in the rest of the Papers, and also shows that the number of sample cases is 292 , including Table (10): Comparison between 3 papers regarding MSTS score

\begin{tabular}{|c|c|c|c|c|}
\hline \multirow[t]{2}{*}{ Papers } & MSTS score & \multirow{2}{*}{$\begin{array}{c}\text { Test } \\
\text { value }\end{array}$} & \multirow[t]{2}{*}{ P-value } & \multirow[t]{2}{*}{ Sig. } \\
\hline & Mean \pm SD & & & \\
\hline Bai et al. ${ }^{(21)}$ & $21.48 \pm 6.05$ & \multirow[t]{3}{*}{$1203.181 \bullet$} & \multirow[t]{3}{*}{0.000} & \multirow[t]{3}{*}{$\mathrm{HS}$} \\
\hline He et al. ${ }^{(22)}$ & $27.35 \pm 1.6$ & & & \\
\hline Kamal and Muhamad ${ }^{(23)}$ & $79.02 \pm 10.6$ & & & \\
\hline
\end{tabular}

P-value >0.05: Non significant (NS); P-value <0.05: Significant (S); P-value< 0.01: highly significant (HS) *: Chi-square test; $\bullet$ : Independent t-test

This table shows the comparison of MSTS Score time in only 3 of the 18 Papers, because no data is mentioned for any type in the rest of the Papers, and also shows that the number of sample cases is 161, there was highly statistical significant difference between 5 papers regarding MSTS Score.

\section{DISCUSSION:}

GCT is considered to be a benign lesion, despite its potential for local aggression, recurrence, and occasional lung metastases. The frequency of these is approximately 1\%-3\%, which can be higher in cases with local recurrence, especially when located in the soft tissue ${ }^{(20)}$.

A small lesion tends to evolve and lead to the progressive destruction of the affected bone. Therefore, surgical treatment should be indicated and performed as early as possible ${ }^{(20)}$.
33 cases Grade I, 153 Case Grade II and 106 Case Grade III, The Previous table show that there was highly statistical significant difference between 5 papers regarding grade.
Curettage associated with an adjuvant method has been defined as the preferred treatment for most cases of GCT. This option presents a better functional outcome, but is associated with a higher chance of relapse, as evidenced in some studies ${ }^{(22)}$.

Wide resection has the advantage of lower chance of relapse, as it removes the tumor entirely. It is usually reserved for cases of extensive bone destruction, in which joint reconstruction is not feasible ${ }^{(36)}$. Several studies have advocated the use of this technique in Campanacci III tumors, aiming to reduce the risk of recurrence and biomechanical failure ${ }^{(20)}$.

Complete bone resection can also be performed in some cases without marked functional impairment, such as in the ulna, fibula, and small bones of the hand and foot $^{(36)}$.

The aim of this study was to detect best method of treatment of aggressive giant cell tumor whether intralesional curettage or 
resection and replacement with endoprothesis.

As regard the recurrence, the number of sample cases is 981, including 291 cases with recurrence and 690 Cases without recurrence.

In cases of recurrence, patients' main complaint was reappearance of pain. Imaging tests had to be performed to confirm the relapse and determine tumor stage. The incidence of GCT recurrence varies in the literature. Dahlin et al. (24) published a study with $60 \%$ of local recurrence in GCT patients who underwent curettage and grafting, and recommended a more aggressive resection for local control.

McDonald et al. ${ }^{(13)}$ concluded that pathological fracture does not increase the likelihood of tumor recurrence, but the association was not statistically significant. O'Donnell et al. ${ }^{(29)}$ reported that three $(50 \%)$ out of six patients with pathologic fractures evolved with recurrence of the tumor. They concluded that there is a correlation between the occurrence of pathological fractures and tumor recurrence

In Bai et al. (21), there was 1 local recurrence in the curettage group and 2 in the segmental resection group, and the recurrence rates within the groups were $7.1 \%$ ( 1 of 14 patients) and $15.4 \%$ (2 of 13patients), respectively and the average time to recurrence was2 years in the curettage group and 4.5 years in the segmental resection group.

In this systematic review, the number of sample cases was 342, including 164 cases female and 178 Case male with no statistical significant difference between the included studies regarding age and sex.

According to the complications, the number of sample cases was 238 , including 15 cases with complications and 223 case without complications and there was no statistical significant difference between 3 papers $Y \boldsymbol{u}$ et al. (17); Zhang et al. (19) and $\mathrm{He}$ et al. (22) regarding complications.

In $H e$ et al. (22), Nononcologic complications occurred frequently in the EC group than in the SR group in the EC group as six patients had secondary osteoarthritis. In the SR group, joint stiffness developed in four patients, while other complications were not observed. Postoperative fracture infection, and failure of internal fixation were not observed in both groups.

As regard the tumor location, the number of sample cases was 315 , including 169 cases distal Femur and 146 Case proximal tibia with no statistical significant difference between 6 papers $Y u$ et al. ${ }^{(17)}$; Wan et al. ${ }^{(18)}$; Zhang et al. ${ }^{(19)}$; Rigollino et al. (20); He et al. (22) and Kamal and Muhamad $^{(23)}$ regarding tumor location.

Regarding the follow up time, the number of sample cases was 166 with highly statistical significant difference between 4 papers $Y u$ et $a l .{ }^{(17)}$; Wan et $a l .{ }^{(18)}$; Bai et al. ${ }^{(21)}$ and He et al. ${ }^{(22)}$ regarding follow-up time.

According to the tumor grading, the number of sample cases is 292 , including 33 cases Grade I, 153 Case Grade II and 106 Case Grade III and there was highly statistical significant difference between 5 papers $Y u$ et $a l .{ }^{(17)}$; Wan et al. ${ }^{(18)}$; Zhang et al. ${ }^{(19)}$; Bai et al. ${ }^{(21)}$ and $\mathrm{He}$ et al. ${ }^{(22)}$ regarding Grade.

As regard the MSTS score, the number of sample cases is 161 with highly statistical significant difference between 5 papers $\mathrm{Bai}$ et $a .^{(21)}$; He et al. ${ }^{(22)}$ and Kamal and Muhamad $^{(23)}$ regarding MSTS Score.

He et $a l^{(22)}$ in his study showed a significant difference in the mean MSTS score between the two groups (EC group, 28.2 points; range, 24-30points, 95\% CI 27.8-28.5; SR group, 26.5 points; range, 27.7-28.5 points, 95\% CI 0.58-0.94; $\mathrm{p}<0.001)$ and all patients resumed normal activity after operation and concluded that 
EC and SR for GCTB around the knee joint can achieve satisfactory oncological prognosis, but we should individually select the most suitable surgical method according to Campanacci grade, age, and long-term complications of patients and take into account the functional prognosis to ensure excellent oncological prognosis.

In Bai et al. ${ }^{(21)}$, the average MSTS score was 21.56.0, and the rate of good to excellent findings was $59.3 \%$ (16 of 27 patients). In the curettage group, the average MSTS score was 26.14.1 and the rate of good to excellent findings was $92.9 \%$ (13of 14 patients). The mean MSTS score in the segmental resection group was 16.52.9, with a rate of good to excellent findings of $23.1 \%$ (3 of 13 patients) and its results showed that patients with Campanacci grade II or with curettage achieved higher postoperative MSTS scores than patients with Campanacci grade III or with segmental resection. And through his study concluded that more complications occurred in the segmental resection group and the postoperative shoulder joint function of patients after segmental resection was much poorer than that in the curettage group and recommended that the method using segmental resection and reconstruction with a large segmental osteo-articular allograft is considered unadvisable and suggested that extensive curettage should be used in the treatment of proximal humerus GCTs as much as possible.

On the other side, Wan et al. ${ }^{(18)}$ revealed that wide en bloc resection and prosthesis replacement can not only reduce the rerecurrence risk for aggressive (grade III) recurrent GCT, but also maintain relatively good limb function. Moreover, intra-lesional treatment is a good option for less aggressive (grade II) recurrent tumors because it can preserve optimal limb function and increase bone strength by PMMA bone cementing. Accordingly, the treatment for recurrent GCT should be individualized depending on the biological behavior of tumor and the integrity of bone structure and adjacent joint, which is critical for decreasing the postoperative complications and re-recurrence rate, and improving limb function as well.

On the other side, Wang et al. ${ }^{(37)}$ found that surgical curettage with various adjuvant modalities might be considered as the first choice for treatment of high-grade GCTs in weight-bearing areas, especially in young patients, to avoid unnecessary endoprosthesis.

In $Y u$ et $a l .{ }^{(17)}$ study, the long term results of this study indicate that satisfactory clinical results can be achieved by en bloc resection of tumor and reconstruction with prosthesis for GCT around the knee, prosthesis loosening and affected limb shortening being the main long term problems and the authors revealed that prosthetic replacement for GCT should be used only where there is tumor with extensive destruction of the bone structure, pathological fracture, or difficulty in reconstruction after intra-lesional curettage. Otherwise, intra-lesional curettage and reconstruction by various methods is the preferred method.

The authors in Rigollino et al. ${ }^{(20)}$ study believed that from the oncological stand point, the best treatment method for locally advanced knee GCT is extensive resection with reconstruction of the bone defect using non-conventional endoprosthesis. Despite the improvement in intra-lesional resection techniques associated with intraoperative adjuvant methods, the risk of relapse remains high. Due to the complexity of the treatment and its consequences, patient should be aware and well informed about the possible complications and functional losses that may occur as a result of the treatment chosen, as well as the need for new surgical interventions in the medium and long term. 
Finally, in Zhang et al. ${ }^{(19)}$ study, it was shown that tumor curettage offers effective tumor removal without affecting supporting bone. Therefore, this method should be considered the preferred surgical approach, while tumor curettage should be considered for patients with severe bone destruction, or for whom the loading requirements could not be met after reconstruction.

\section{Conclusion:}

Throughout this systematic review, we concluded that Wide resection and extended curettage using adjuvants in treatment of patients with giant cell tumor were equally effective with no statistically significant differences in complications.

\section{REFERENCES:}

1. Sobti A, Agrawal P, Agarwala S, Agarwal M. Giant cell tumor of bone-an overview. Archives of Bone and Joint Surgery. 2016; 4(1): 2 .

2. Tsukamoto S, Mavrogenis AF, Leone G, Righi A, Akahane M, Tanzi P, Kido A, Honoki K, Tanaka Y, Donati DM, Errani C. Denosumab does not decrease the risk of lung metastases from bone giant cell tumour. International Orthopaedics. 2019; 43(2): 4839.

3. Lee JC, Liang CW, Fletcher CD. Giant cell tumor of soft tissue is genetically distinct from its bone counterpart. Modern Pathology. 2017; 30(5): 728-33.

4. Larsson SE, Lorentzon R, Boquist L. Giantcell tumor of bone. A demographic, clinical, and histopathological study of all cases recorded in the Swedish Cancer Registry for the years 1958 through 1968. J Bone Joint Surg Am. 1975; 57(2): 167-73.

5. Jeys LM, Suneja R, Chami G, Grimer RJ, Carter SR, Tillman RM. Impending fractures in giant cell tumors of the distal femur: incidence and outcome. Int Orthop. 2006; 30(2): 135-8.

6. Turcotte RE. Giant cell tumor of bone. Orthop Clin North Am. 2006; 37(1): 35-51.
7. Lewis VO, Wei A, Mendoza T, Primus F, Peabody T, Simon MA. Argon beam coagulation as an adjuvant for local control of giant cell tumor. Clin Orthop Relat Res. 2007; 454(1): 192-7.

8. Lichtenstein L. Bone tumors, 4th edn. Mosby, St. Louis, 1972; 135-165.

9. Dahlin DC, Cupps RE, Johnson EW. Giantcell tumor: a study of 195 cases. Cancer, 1970; 25:1061-1070.

10. Hutter RV, Worcester JN, Francis KC. Benign and malignant giant cell tumors of bone. A clinicopathological analysis of the natural history of the disease. Cancer, 1962; 15: 653-690.

11. Marui T, Yamamoto T, Yoshihara H. De novo malignant transformation of giant cell tumor of bone. Skeletal Radiol., 2001; 30: 104-108.

12. Unni KK. Dalin's bone tumors-general aspects and data on 11,087 cases, $5^{\text {th }}$ edn. Lippincott-Raven, Philadelphia, 1996; 263287.

13. Layfield LJ, Bentley RC, Mirra JM. Pseudoanaplastic giant cell tumor of bone. Arch Pathol Lab Med, 1999; 123:163-166.

14. Gong L, Liu W, Sun X, Sajdik C, Tian X, Niu X, Huang X. Histological and clinical characteristics of malignant giant cell tumor of bone. Virchows Archiv. 2012; 460(3): 327-34.

15. Brien EW, Mirra JM, Kessler S. Benign giant cell tumor of bone with osteosarcomatous transformation ("dedifferentiated" primary malignant GCT): report of two cases. Skeletal Radiol., 1997; 26: 246-255.

16. Ortiz-Cruz EJ, Quinn RH, Fanburg JC. Late development of a malignant fibrous histiocytoma at the site of a giant cell tumor. Clin Orthop Relat Res., 1995; 318:199-204.

17. Yu XC, Xu M, Song RX, Fu ZH, Liu XP. Long-term outcome of giant cell tumors of bone around the knee treated by en bloc resection of tumor and reconstruction with prosthesis. Orthop Surg. 2010; 2(3): 211217. 
18. Wan R, Zhang W, Xu J, Hao P, Yang Y, Shen Y, Ding X, Qiu S. The outcome of surgical treatment for recurrent giant cell tumor in the appendicular skeleton. Journal of Orthopaedic Science. 2012; 17(4): 464-9.

19. Zhang S, Zhang J, Wang X. Comparison of tumor curettage and resection for treatment of giant cell tumor of the bone around the knee joint. Pak J Med Sci. 2016; 32(3): 662-666.

20. Rigollino AV, Fernando TS, Tanaka MH, Souza MM. Giant cell tumor locally advanced around the knee: treatment and literature review. Rev Bras Ortop. 2017; 52(4): 473-478.

21. Bai WZ, Guo SB, Zhao W, Yu XC, Xu M, Zheng $\mathrm{K}$, Hu YC, Wang F, Zhang GC. Comparison of outcomes of 2 surgical treatments for proximal humerus giant cell tumors: a multicenter retrospective study. Journal of shoulder and elbow surgery. 2019; 28(11): 2103-12.

22. He H, Zeng H, Luo W, Liu Y, Zhang C, Liu Q. Surgical treatment options for giant cell tumors of bone around the knee joint: extended curettage or segmental resection? Frontiers in oncology. 2019; 9: 946.

23. Kamal AF, Muhamad A. Outcomes of En bloc resection followed by reconstruction of giant cell tumor around knee and distal radius. A case series. Annals of Medicine and Surgery. 2020; 49: 61-6.

24. Dahlin DC, Cupps RE, Johnson EW. Giantcell tumor: a study of 195 cases. Cancer. 1970; 25(5): 1061-1070.

25. Goldenberg RR, Campbell CJ, Bonfiglio M. Giant-cell tumor of bone: an analysis of two hundred and eighteen cases. JBJS. 1970; 52(4): 619-64.

26. Sheth DS, Healey JH, Sobel M, Lane JM, Marcove RC. Giant cell tumor of the distal radius. The Journal of hand surgery. 1995; 20(3): 432-40.

27. Jacobs PA, Clemency RE. The closed cryosurgical treatment of giant cell tumor.
Clinical orthopaedics and related research. 1985; 192: 149-58.

28. Waldram MA, Sneath RS. Giant-Cell Tumor of bone-analysis of 20 cases treated by curettage without bone-graft. In Journal of Bone and Joint Surgery-British Volume, 1987; 69(3): 492-492.

29. O'Donnell RJ, Springfield DS, Motwani HK, Ready JE, Gebhardt MC, Mankin HJ. Recurrence of giant-cell tumors of the long bones after curettage and packing with cement. J Bone Joint Surg Am. 1994; 76(12): 1827-1833.

30. Blackley HR, Wunder JS, Davis AM, White LM, Kandel R, Bell RS. Treatment of giant-cell tumors of long bones with curettage and bone-grafting. JBJS. 1999; 81(6): 811-20.

31. Mundy GR. Metastasis to bone: Causes, consequences and therapeutic opportunities. Nat Rev Cancer 2002;2:584-593.

32. Clézardin P. Bisphosphonates' antitumor activity: an unravelled side of a multifaceted drug class. Bone 2011; 48: 71-79.

33. Lau CP, Huang L, Wong KC. Comparison of the anti- tumor effects of denosumab and zoledronic acid on the neoplastic stromal cells of giant cell tumor of bone. Connect Tissue Res 2013; 54:439-449.

34. Balke M, Neumann A, Szuhai K. A short- term in vivo model for giant cell tumor of bone. BMC Cancer 2011; 11: 241.

35. Yang T, Zheng XF, Li M. Stimulation of osteogenic differentiation in stromal cells of giant cell tumour of bone by zoledronic acid. Asian Pac $J$ Cancer Prev 2013;14:5379-5383.

36. Domovitov SV, Healey JH. Primary malignant giant-cell tumor of bone has high survival rate. Ann Surg Oncol., 2010; 17: 694-701.

37. Wang HC, Chien SH, Lin GT. Management of grade III giant cell tumors of bones. J Surg Oncol. 2005; 92(1): 46-51. 


\section{الملخص العربي}

يعثبر ورم الخلايا العملاقة في العظام مرض حميد، على الرغم من احتمالية حدوث تعدى موضعي، وعودة المرض، ونقائل رئوية عرضية.

تميل الإصابة الصغيرة إلى التطور وتؤدي إلى التدمير التدريجي للعظم المصاب. لذللك، يجب الإشارة إلى العلاج الجراحي وإجر اء العلاج في أقرب وقت مهكن.

تم تحديد الكثط المرتبط بالطريقة المساعدة على أنه العلاج المفضل لمعظم حالات ورم الخلابا العملاقة.

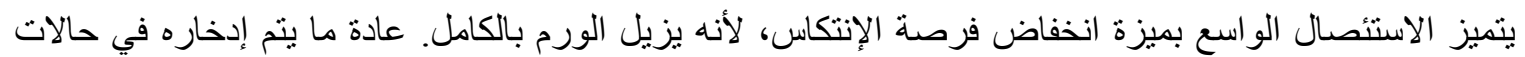

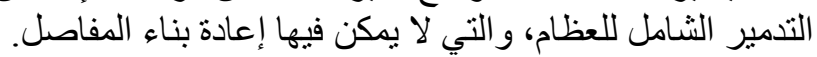
الهدف من هذه الدراسة هو الكثف عن أفضل طريقة لعلاج ورم الخلايا العملاقة الثرس سواء كان الكثط داخل

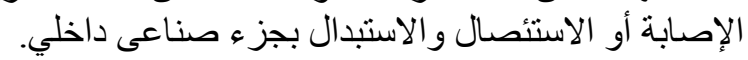
أظهر التحليل الإحصائي ما يلي:

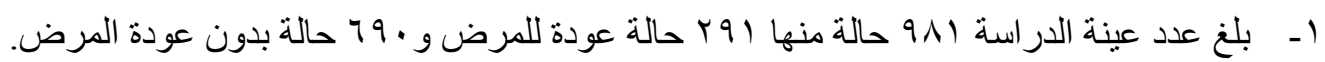

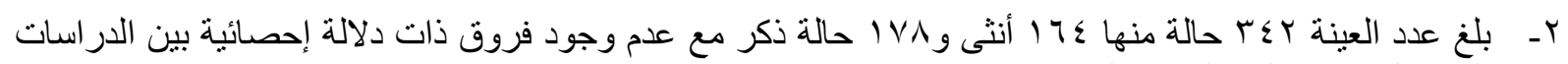
المشمولة فيما يتعلق بالعمر و الجنس.

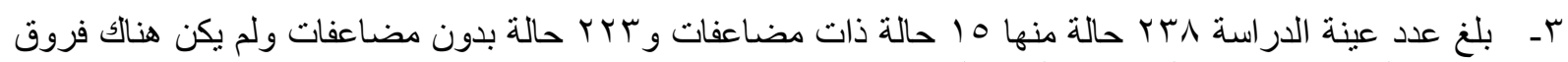
ذات دلالة إحصائية بين الدراسات المشمولة.

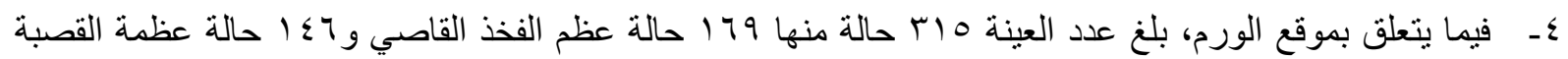

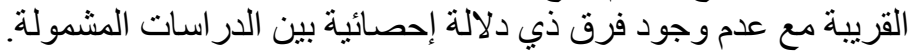

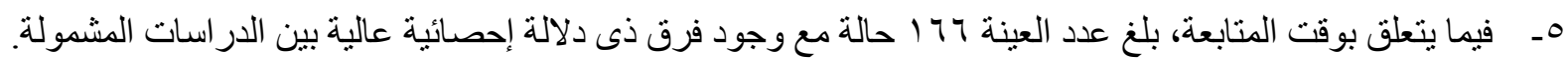

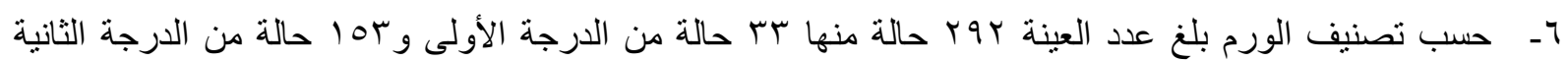
و 7 ـ 1 حالة من الدرجة الثالثة وكان هناك فروق ذات دلالة إحصائية عالية بين الدراسات المشمولة.

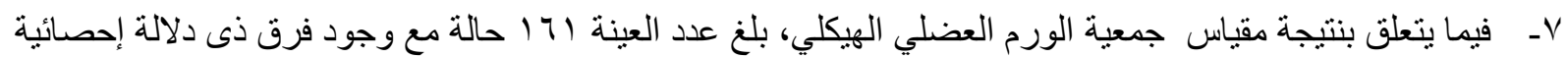
عالية بين الدراسات المشمولة.

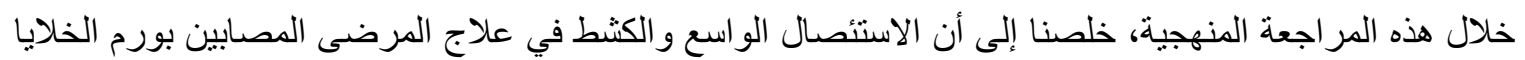

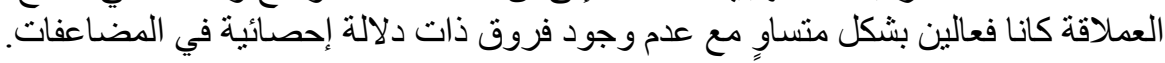

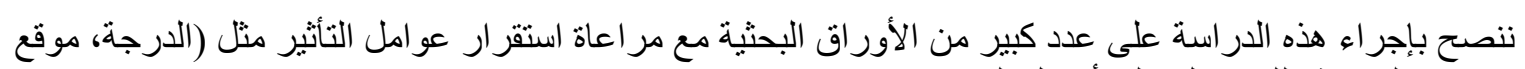
الورم، ووقت المتابعة) للحصول على لنى أفضل النتائج. 